\title{
IMPLEMENTASI APLIKASI PANDUAN WISATA PROVINSI SULAWESI SELATAN BERBASIS ANDROID
}

\author{
Kurniati Asmar ${ }^{1)}$,Yusran Bobihu ${ }^{2)}$, Nur Afif ${ }^{3)}$ \\ ${ }^{1,2}$ Balai Besar Pengkajian dan Pengembangan Komunikasi dan Informatika Makassar \\ ${ }^{1,2}$ Jl. Prof. Dr. Abdurrahman Basalamah II No.25, Makassar, 90123, Telp/Fax: 0411-4460084 \\ ${ }^{3}$ Fakultas Sosial dan Ilmu Politik, Universitas Hasanuddin \\ ${ }^{3}$ Jl. Perintis Kemerdekaan km. 10 Tamalanrea, Makassar, 90245, Telp/Fax: 0411-586001 \\ E-mail: kurniati.asmar@gmail.com ${ }^{1)}$,yusran.bobihu@uin-alauddin.ac.id ${ }^{2)}$,pipo.limpuche@yahoo.com ${ }^{3)}$
}

\begin{abstract}
Abstrak - materi pengenalan atau promosi pariwisata di Provinsi Sulawesi Selatan melalui beberapa media baik itu media cetak atau pun elektronik yang saat ini beredar, belum cukup mendukung peningkatan promosi pariwisata Provinsi Sulawesi Selatan. Padahal Publikasi dan promosi pariwisata yang baik dapat menjadi sebuah peluang untuk menaikkan taraf kehidupan masyarakat, sehingga dapat menjadi sumber devisa yang besar bagi suatu daerah. Penelitian ini menggunakan metode penelitian kualitatif dengan strategi design and creation sedang metode pengumpulan data yang digunakan yaitu observasi, wawancara, dan studi literatur. Adapun metode perancangannya menggunakan metode Rapid Application Development (RAD). Hasil dari pengujian aplikasi ini menyimpulkan bahwa fungsi yang diharapkan semuanya berhasil sesuai dengan keinginan. Kesimpulannya bahwa Aplikasi Jelajah Sulawesi Selatan dapat dijadikan sebagai media panduan pariwisata Provinsi Sulawesi Selatan.
\end{abstract}

Kata Kunci : Sistem Informasi, Rapid Aplication Development, Pariwisata

\section{PENDAhuluan}

$\begin{array}{rrr}\text { Sebagai rangkaian usaha } & \text { untuk } \\ \text { meningkatkan pendapatan daerah, } & \text { Dinas }\end{array}$ Kebudayaan dan Pariwisata Provinsi Sulawesi Selatan melakukan upaya promosi melalui beberapa media baik itu media cetak atau pun elektronik yang saat ini beredar, namun upaya tersebut belum cukup mendukung peningkatan promosi pariwisata. Seperti situs web resmi dari beberapa kabupaten yang menyediakan fitur untuk bagian kepariwisataan tidak dapat berfungsi dengan baik. Bahkan, ada beberapa dari situs web resmi tersebut yang sudah tidak aktif. Sementara situs web provinsi sendiri, di fitur kepariwisataanya hanya memberikan informasi pariwisata dari beberapa kabupaten.

Ada pun dinas kepariwisataan provinsi telah mengupayakan banyak hal untuk mempromosikan pariwisata Sulawesi Selatan, baik dengan menggunakan metode langsung seperti mengadakan atau mengikuti seminar di dalam maupun di luar negeri, melakukan promosi pada perusahan-perusahaan yang bergerak di bidang pariwisata untuk bekerjasama dalam memasarkan produk-produk wisata. Serta menggunakan metode tidak langsung yang dilakukan apabila terjadi keterbatasan waktu, dana, sarana, dan lainnya. Metode tidak langsung ini berupa periklanan koran, demo brosur, dan buku kepariwisataan yang kemudian sub dinas pemasaran dan HLWI (Hubungan Lembaga Wisata Internasional) menyebarluaskan melalui pos ke biro perjalanan yang ada di luar negeri. Mengadakan hubungan kerjasama dengan biro perjalanan baik dalam negeri maupun luar negeri. Semua itu belumlah maksimal, karena masih banyak masyarakat yang belum tahu keberadaan pariwisata unggulan yang dimiliki oleh beberapa kabupaten yang tidak terpublikasi dengan baik. 
Penggunaan mobile device seperti smartphone sudah menjadi hal yang wajar dikalangan wisatawan. Maka dari itulah sudah seharusnya ada sebuah sistem atau aplikasi panduan wisata yang berbasis mobile device untuk memajukan pariwisata Sulawesi Selatan. Smartphone berkembang dengan berbagai jenis merek dengan beberapa platform salah satunya Android. Android memiliki berbagai kelebihan dan perkembangan Android sangat signifikan. Salah satu kelebihan platform Android adalah ketersediaan platform yang sifatnya terbuka bagi para pengembang untuk menciptakan aplikasi.

Dalam kondisi persaingan pasar bidang kepariwisataan yang ketat, kecepatan dan ketepatan informasi serta efisiensi waktu dan biaya sangat menentukan berhasil atau tidaknya strategi rencana-rencana yang telah disusun untuk meraih kesempatan dan peluang pasar. Sehingga pemanfaatan teknologi informasi yang dipadupadankan dengan keterampilan ilmu sistem informasi perlu digunakan untuk meningkatkan penyediaan informasi agar dapat mendukung pencapaian tujuan yang dilakukan oleh manajemen pemasaran pariwisata.

Oleh karena itu, untuk memberikan kemudahan kepada wisatawan serta pencapaian tujuan pemasaran pariwisata Sulawesi Selatan, dijadikanlah teknologi informasi sebagai solusi permasalahan ini

\section{Metodologi Penelitian}

Dalam melakukan penelitian ini, jenis penelitian kualitatif lapangan yang digunakan adalah Design and Creation. Dipilihnya jenis penelitian ini dikarenakan konsep dari design and creation, selain melakukan penelitian tentang judul ini, juga akan dikembangkan produk berdasarkan penelitian yang telah dilakukan oleh penulis.

Adapun lokasi penelitian ini dilakukan di Dinas Kebudayaan dan Pariwisata Provinsi Sulawesi Selatan, yang bertempat di Gedung Mulo Kota Makassar. Alasan dipilihnya lokasi tersebut karena kantor tersebut merupakan pusat informasi kebudayaan dan pariwisata Provinsi Sulawesi Selatan, dan juga merupakan STIC (Sulawesi Tourism Information Center).

Sumber data pada penelitian ini adalah menggunakan Libarary Research yang merupakan cara mengumpulkan data dari berbagai buku, jurnal, skripsi, tesis maupun literatur lainnya yang dapat dijadikan acuan pembahasan dalam masalah ini. Penelitian ini keterkaitan pada sumber-sumber data online atau internet ataupun hasil dari penelitian sebelumnya sebagai bahan referensi bagi peneliti sebelumnya.

Dalam penelitian ini, metode perancangan aplikasi perangkat lunak yang akan digunakan yaitu metode Rapid Application Development $(R A D)$. Metode ini merupakan salah satu metode yang digunakan untuk mengembangkan aplikasi android (Android Mobile Development). Metode ini dipilih berdasarkan pendapat James Martin "Rapid Application Development (RAD) yaitu pengembangan siklus yang dirancang yang dapat memberikan pengembangan yang jauh lebih cepat dan hasil yang lebih berkualitas tinggi dari pada yang dicapai dengan siklus hidup tradisional. Metode pengembangan aplikasi perangkat lunak ini terdiri dari 4 tahapan yaitu Requirements Planning Phase, User Design Phase, Construction Phase dan Cotuver Phase. (Arzan Muharom, 2013).

\section{HASIL DAN PEMbahasan}

Disamping menggunakan jasa pemandu wisata, biasanya wisatawan juga dapat menggunakan sarana bantuan seperti brosurbrosur yang dilengkapi peta yang bisa didapatkan di Dinas Kebudayaan dan Pariwisata Provinsi Sulawesi Selatan, namun jumlahnya terbatas, jadi kemungkinan brosur dan peta tidak dapat diperoleh dengan mudah. 


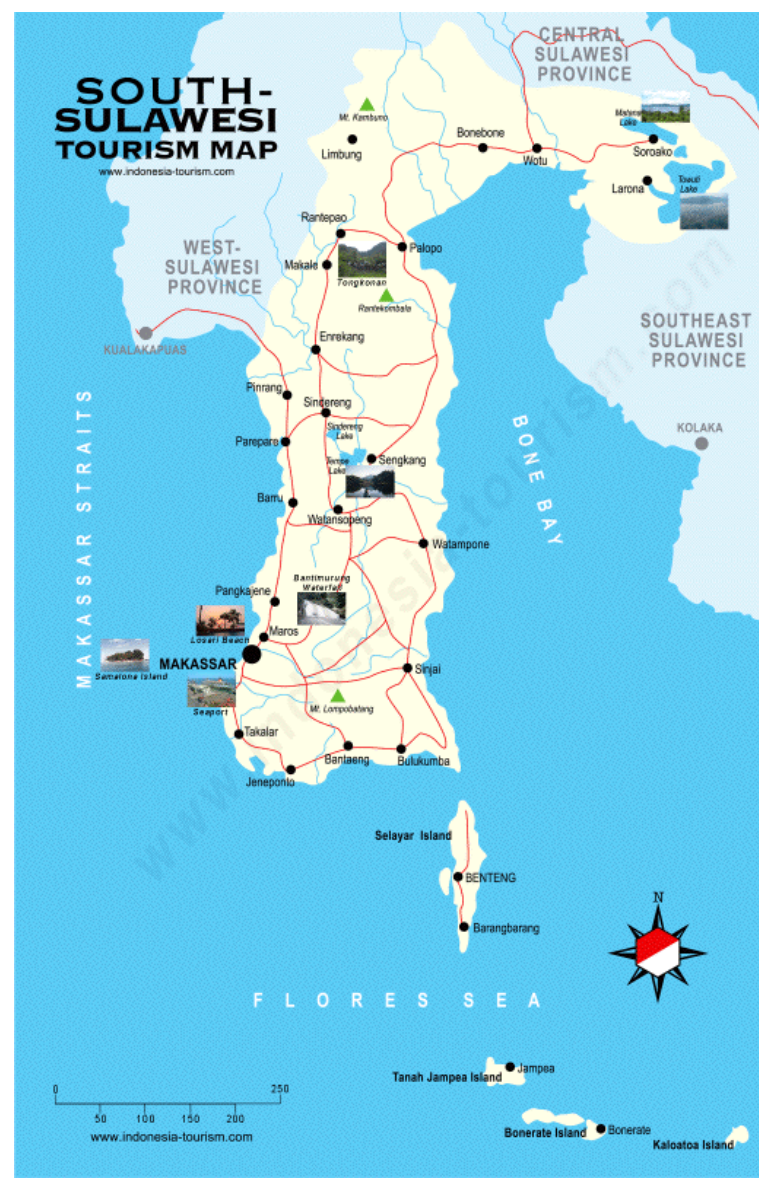

Gambar IV.1 South-Sulawesi Tourism Map

(wisataindonesiatimur.wordpress.com)

Jika memiliki koneksi internet, wisatawan dapat memperoleh informasi yang lumayan banyak baik itu dari blog pribadi, media sosial, dan laman tentang pariwisata Provinsi Sulawesi Selatan, sehingga dibutuhkan kesabaran membuka satu per satu laman-laman yang tersedia.

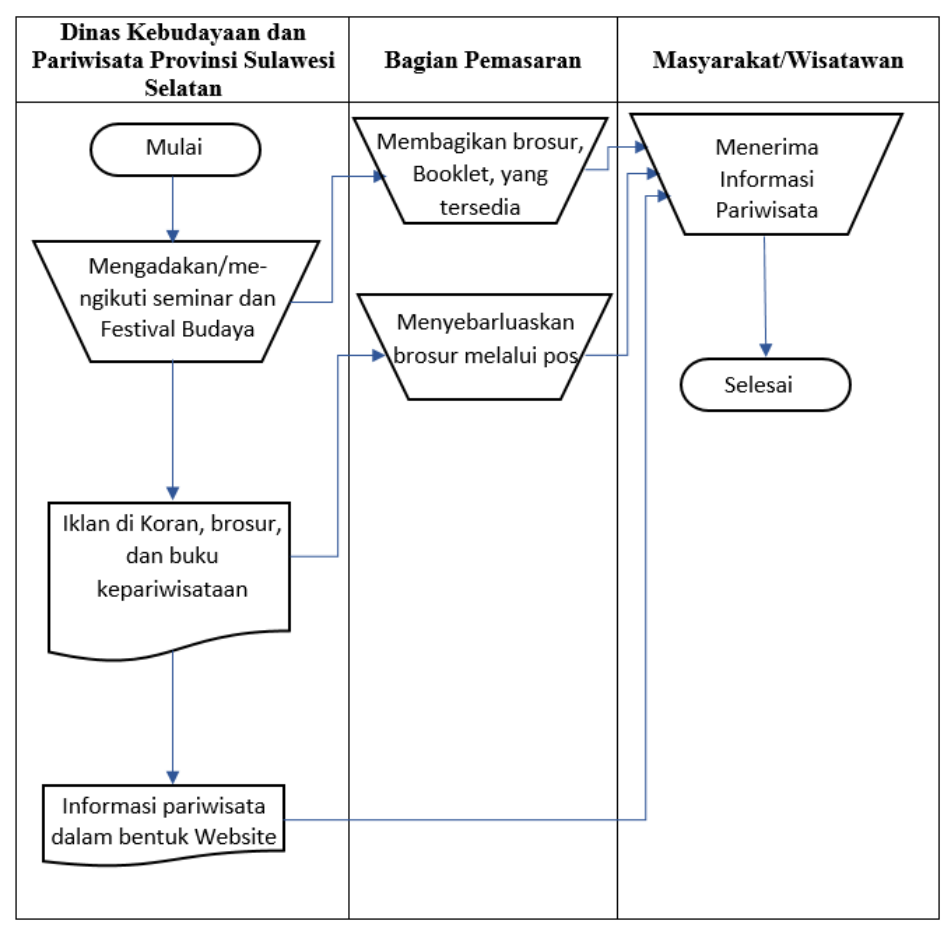

Gambar IV. 2 Flowmap Sistem yang sedang berjalan

a. Antarmuka Sub Menu Destinasi

Antarmuka ini menampilkan menu destinasi yang terdiri dari enam tombol, yang dapat dipilih.

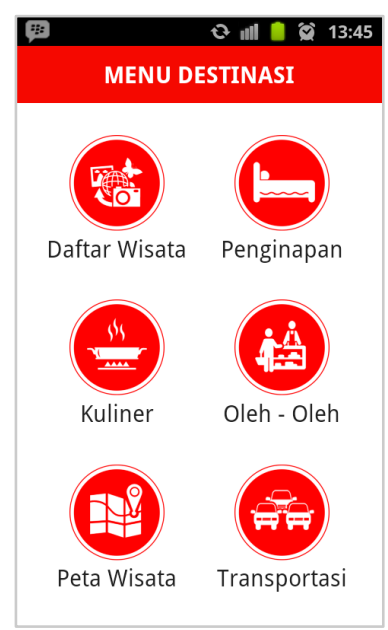

Gambar V.3 Antarmuka Sub Menu Destinasi

Tombol pilih wisata menyediakan informasi pariwisata dari setiap daerah di Provinsi Sulawesi Selatan yang dibagi atas dua ketergori yaitu, wisata alam dan wisata pendidikan. Tombol penginapan menyediakan infromasi penginapan yang ada disetiap daerah di Provinsi Sulawesi Selatan. Tombol kuliner menyediakan informasi kuliner khas Provinsi Sulawesi Selatan. Tombol 
oleh-oleh menyediakan informasi oleh-oleh yang ada disetiap daerah di Provinsi Sulawesi Selatan. Tombol peta wisata menyediakan fitur google map yang diharapkan dapat memandu pengguna ke lokasi-lokasi wisata yang ada di Provinsi Sulawesi Selatan. Sementara tombol transportasi, menyediakan informasi jenis transportasi apa saja yang ada di Provinsi Sulawesi Selatan, dengan fitur tambahan yang dapat menyambungkan ke situs website reservasi online tiket bus, reservasi online tiket kapal, dan flight status Bandar Udara Sultan Hasanuddin.

\section{d. Antarmuka Menu Pilih Wisata}

Menu pilih wisata terbagi atas dua kategori yaitu kategori wisata alam yang terdiri dari 45 objek wisata dan kategori wisata pendidikan terdiri dari 34 objek wisata yang diunggulkan dari setiap kabupaten/kota di Provinsi Sulwesi Selatan.
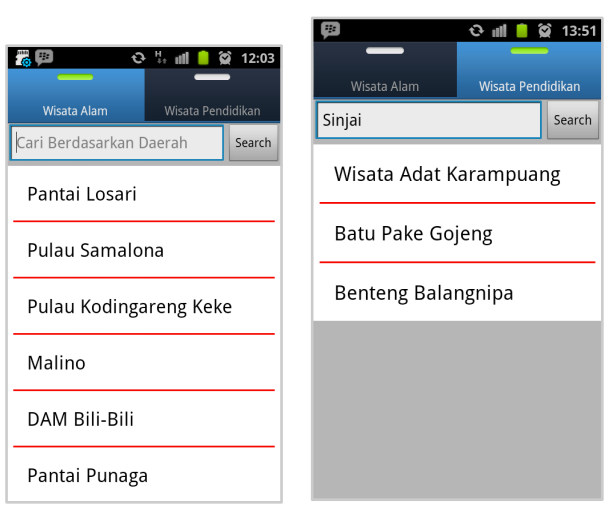

Gambar V.4 Antarmuka Menu Pilih Wisata

Setiap list memiliki informasinya masing-masing, dan fitur pencari dapat memudahkan pengguana mencari berdasarkan kabupaten/kota dan lain sebagainya.

b. Antarmuka Penampil Informasi Wisata Alam Antarmuka ini menampilkan informasi sesuai list objek wisata yang dipilih dari 45 objek wisata yang masuk dalam kategori wisata alam.

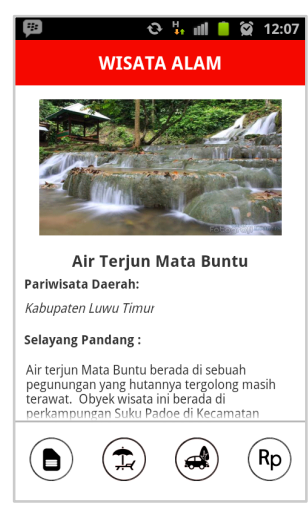

Gambar V.5 Antarmuka Penampil Informasi Wisata Alam

Antarmuka ini menampilkan informasi seperti, gambar objek wisata dilengkapi dengan tomboltombol yang menyediakan informasi selayang pandang, fasilitas, akses dari bandara, dan biaya masuk.

\section{f. Penampil Informasi Wisata Pendidikan}

Antarmuka ini menampilkan informasi sesuai list objek wisata yang dipilih dari 34 objek wisata yang masuk dalam kategori wisata pendidikan.

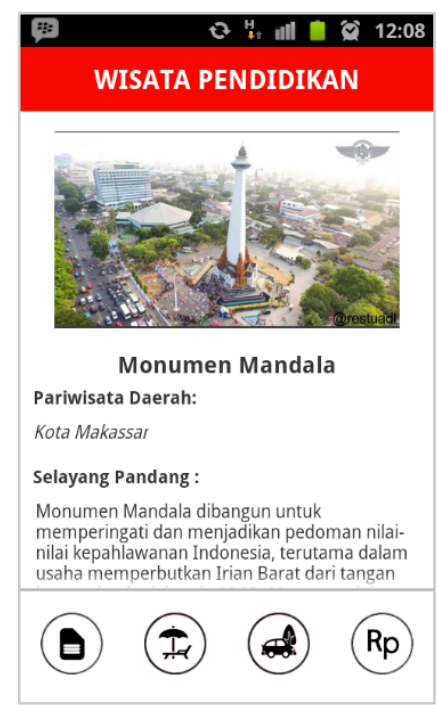

Gambar V.6 Antarmuka Penampil Informasi Wisata Pendidikan

Antarmuka ini menampilkan informasi seperti, gambar objek wisata dilengkapi dengan tomboltombol yang menyediakan informasi selayang pandang, fasilitas, akses dari bandara, dan biaya masuk.

\section{g. Antarmuka Menu Penginapan}


Menu penginapan menyediakan 56 list penginapan dari berbagai kelas yang ada di Provinsi Sulwesi Selatan.

\begin{tabular}{|c|c|}
\hline \multicolumn{2}{|c|}{ 广 } \\
\hline PENGINAPAN & Lainnya \\
\hline Cari Penginapan & Search \\
\hline \multicolumn{2}{|c|}{ Makassar. Pondok Sanrila } \\
\hline \multicolumn{2}{|c|}{$\begin{array}{l}\text { Makassar. Hotel Makassar } \\
\text { Metro }\end{array}$} \\
\hline \multicolumn{2}{|c|}{$\begin{array}{l}\text { Makassar. Hotel Sahid } \\
\text { Makassar }\end{array}$} \\
\hline \multicolumn{2}{|c|}{$\begin{array}{l}\text { Makassar. Imperial } \\
\text { Aryaduta Hotel Makassar }\end{array}$} \\
\hline \multicolumn{2}{|c|}{$\begin{array}{l}\text { Makassar. Grand Clarion } \\
\text { Hotel }\end{array}$} \\
\hline \multicolumn{2}{|c|}{$\begin{array}{l}\text { Makassar. Hotel Losari } \\
\text { Pantai }\end{array}$} \\
\hline
\end{tabular}

Gambar V.7 Antarmuka Menu Penginapan

Setiap list memiliki informasinya masing-masing, dan fitur pencari dapat memudahkan pengguana mencari berdasarkan kabupaten/kota dan lain sebagainya.

h. Antarmuka Penampil Informasi Penginapan

Antarmuka ini menampilkan informasi sesuai list penginapan yang dipilih dari 56 penginapan yang telah diinput di dalam database.

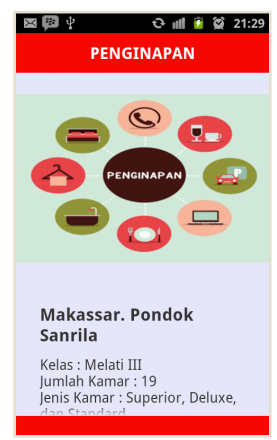

Gambar V.8 Antarmuka Penampil Informasi Penginapan

Antarmuka ini menampilkan informasi seperti, kelas penginapan, jumlah kamar, jenis kamar, fasilitas tambahan, alamat, dan nomor telepon penginapan.

i. Antarmuka Menu Kuliner
Antarmuka ini menampilkan 19 jenis kuliner khas yang patut dicoba jika berada di Provinsi Sulawesi Selatan. Setiap list memiliki informasinya masing-masing, dan fitur pencari dapat memudahkan pengguana mencari berdasarkan nama makanannya.

j. Antarmuka Penampil Informasi Kuliner

Antarmuka ini menampilkan informasi sesuai list kuliner yang dipilih dari 19 kuliner khas yang telah diinput di dalam database.

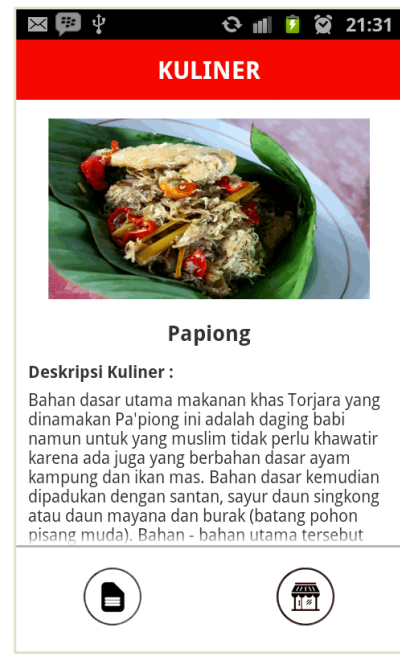

Gambar V.10 Antarmuka Penampil Informasi Kuliner

Antarmuka ini menampilkan informasi seperti, gambar kuliner dilengkapi dengan tombol-tombol yang menyediakan informasi mengenai deskripsi kuliner, dan rumah makan yang menyediakan kuliner tersebut.

\section{k. Antarmuka Menu Oleh-oleh}

Menu oleh-oleh menyediakan 44 jenis oleh-oleh khas dari berbagai daerah yang ada di Provinsi Sulwesi Selatan.

\begin{tabular}{|l|l|}
\hline \multicolumn{2}{|c|}{ OLEH - OLEH } \\
\hline Cari Oleh - Oleh & Search \\
\hline Makassar. Minyak Tawon \\
\hline Makassar. Krupuk Bawang \\
\hline $\begin{array}{l}\text { Makassar. Otak - Otak Ikan } \\
\text { Tenggiri }\end{array}$ \\
\hline Gowa. Tenteng Malino \\
\hline $\begin{array}{l}\text { Gowa. Sirup Pisang Ambon } \\
\text { DHT }\end{array}$ \\
\hline Gowa. Dodol \\
\hline
\end{tabular}


Gambar V.11 Antarmuka Menu Oleh-oleh

Setiap list memiliki informasinya masing-masing, dan fitur pencari dapat memudahkan pengguana mencari berdasarkan kabupaten/kota dan lain sebagainya.

1. Antarmuka Penampil Informasi Oleh-oleh

Antarmuka ini menampilkan informasi sesuai list oleh-oleh yang dipilih dari 44 oleh-oleh khas yang telah diinput di dalam database.

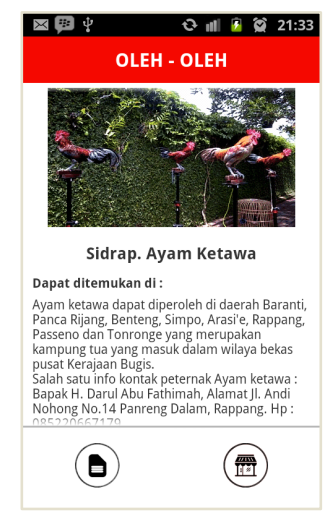

Gambar V.12 Antarmuka Penampil Informasi Oleh-oleh

Antarmuka ini menampilkan informasi seperti, gambar makanan dilengkapi dengan tomboltombol yang menyediakan informasi mengenai deskripsi oleh-oleh, dan tempat yang menyediakan oleh-oleh tersebut.

\section{m. Antarmuka Menu Peta Wisata}

Antarmuka ini menampilkan lokasi-lokasi wisata dalam kawasan Provinsi Sulawesi Selatan dengan menggunakan layanan google map android $v 2$.

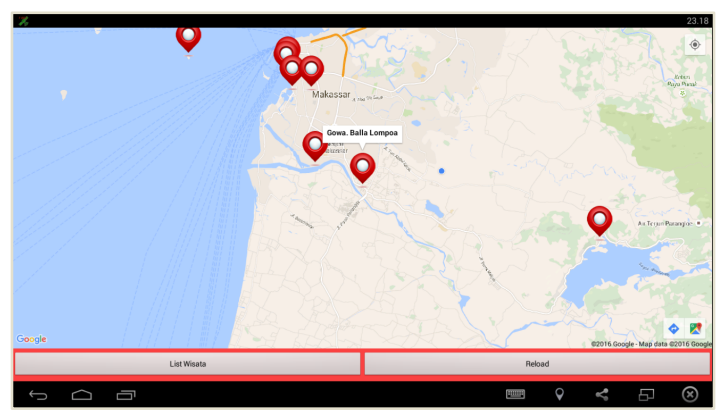

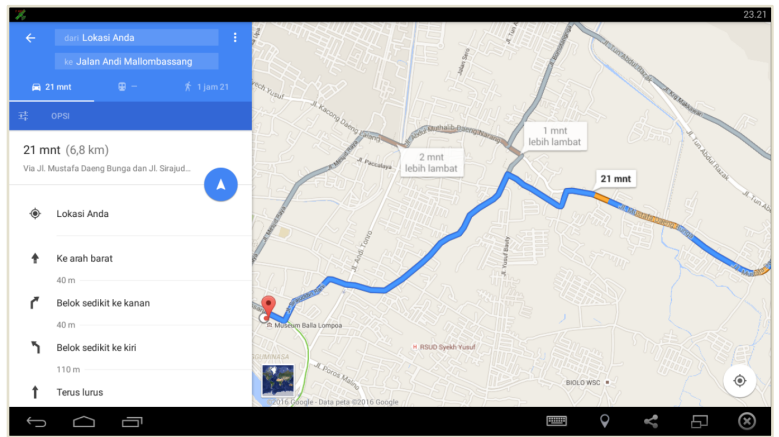

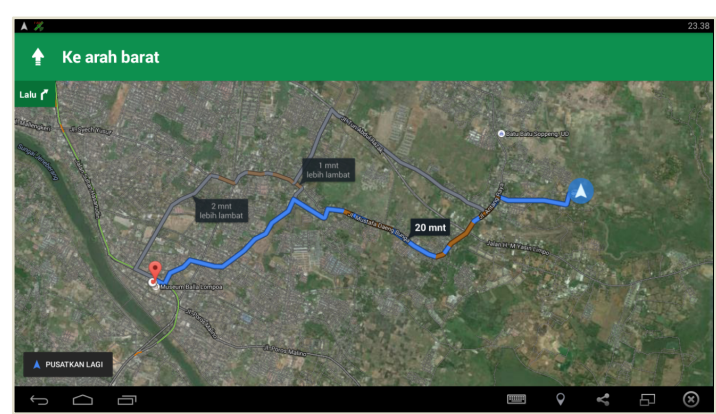

Gambar V.13 Antarmuka Menu Peta Wisata

n. Antarmuka List Peta Wisata

Antarmuka list peta wisata menampilkan 49 objek wisata yang diunggulkan dari kabupaten/kota yang ada di Provinsi Sulawesi Selatan, yang kemudian dapat dilihat lokasinya melalui aplikasi ini dengan layanan dari google map android $v 2$.

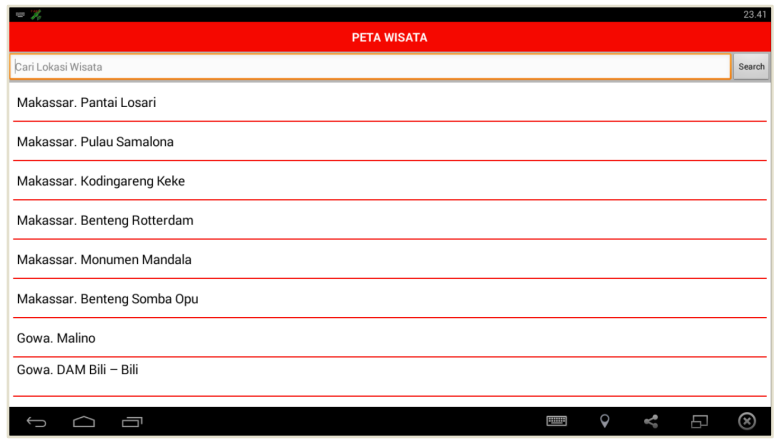

Gambar V.14 Antarmuka List Peta Wisata Setiap list memiliki latitude dan longitude-nya masing-masing, dan fitur pencari dapat memudahkan pengguana mencari berdasarkan kabupaten/kota dan lain sebagainya.

o. Antarmuka Peta Wisata Berdasarkan List Peta Wisata

Antarmuka ini menampilkan lokasi wisata sesuai dengan objek wisata yang dipilih di list peta wisata yang kemudian menampilkan map 
dengan menggunakan layanan google map android $v 2$.
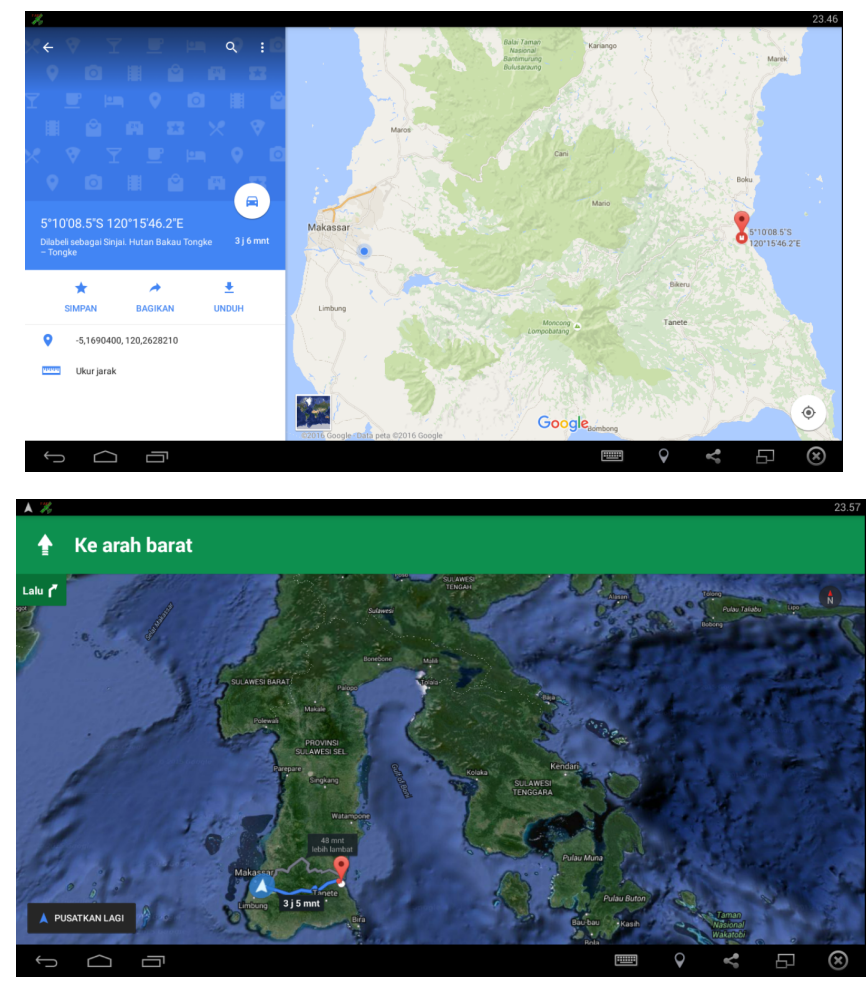

Gambar V.15 Antarmuka Peta Wisata

Berdasarkan List Peta Wisata

p. Antarmuka Menu Transportasi

Menu transportasi dibagi atas tiga ketegori yaitu, darat, laut, dan udara. Masing-masing kategori tersebut memiliki dua tombol.

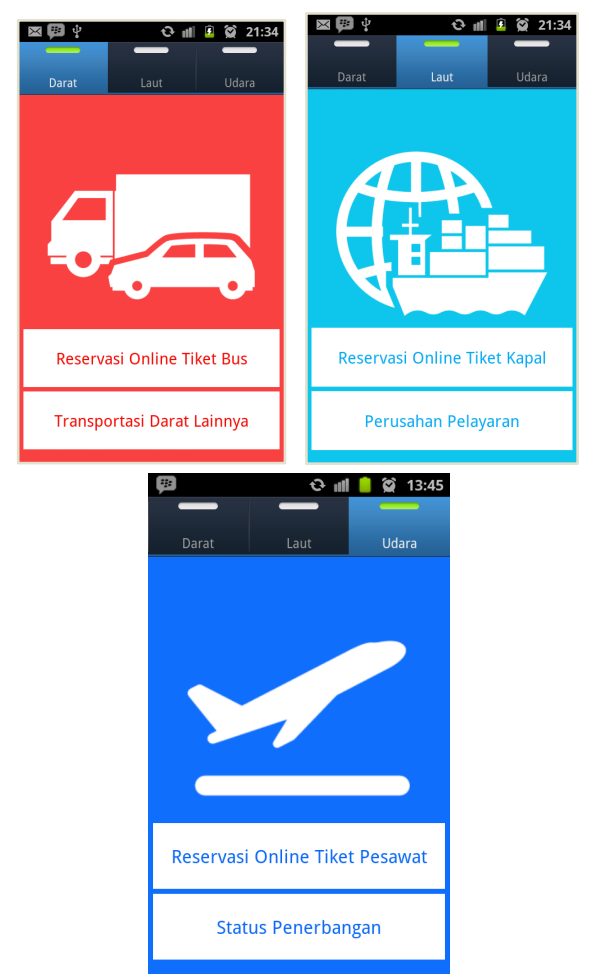

Gambar V.16 Antarmuka Menu Transportasi
Khusus tombol reservasi online pada transportasi kategori darat dan laut dan tombol status penerbangan pada transportasi udara membutuhkan koneksi internet.

q. Antarmuka Informasi Transportasi

Antarmuka informasi Transportasi menampilkan informasi transportasi yang ada di Provinsi Sulawesi Selatan berdasarkan tombol yang dipilih.

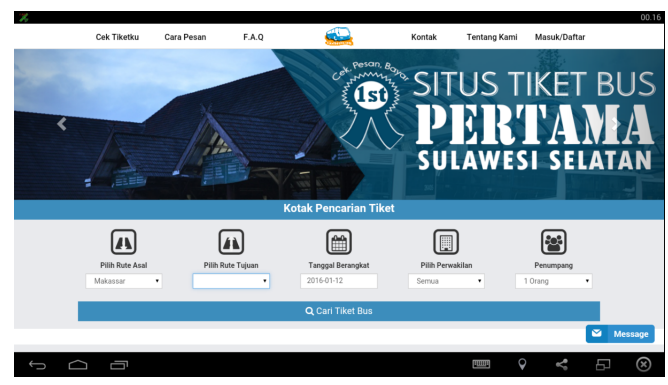

Gambar V.17 Antarmuka Informasi Transportasi Reservasi online Tiket Bus

Tombol reservasi online menghubungkan aplikasi dengan situs reservasi online tiket bus Provinsi Sulawesi Selatan yakni, http://tiketbusku.com/. Diharapkan dengan ini pengguna dapat mudah melakukan pemesanan tiket bus untuk perjalanan wisata di daerah yang ada di Provinsi Sulawesi Selatan.

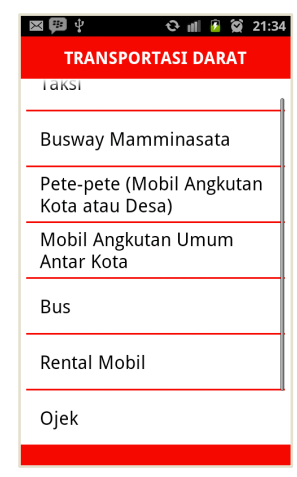

Gambar V.18 Antarmuka Informasi Transportasi Darat Lainnya

Tombol transportasi darat lainnya menampilkan informasi transportasi-transportasi darat yang ada di Provinsi Sulawesi Selatan. 


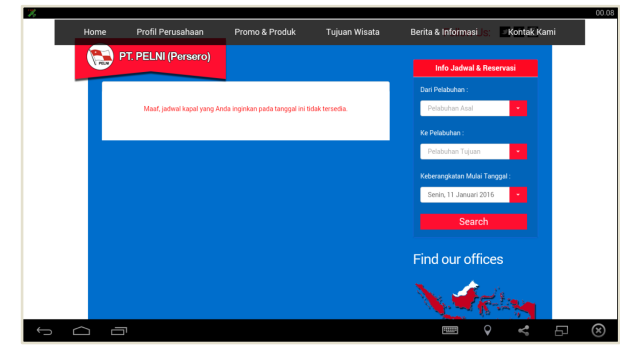

Gambar V.19 Antarmuka Informasi Transportasi Reservasi online Tiket Kapal

Tombol reservasi online menghubungkan aplikasi dengan situs reservasi online tiket kapal PT.PELNI yakni, https://www.pelni.co.id/reservation/schedule.

Diharapkan dengan ini pengguna dapat mudah melakukan pemesanan tiket kapal untuk perjalanan wisata di daerah yang ada di Provinsi Sulawesi Selatan.

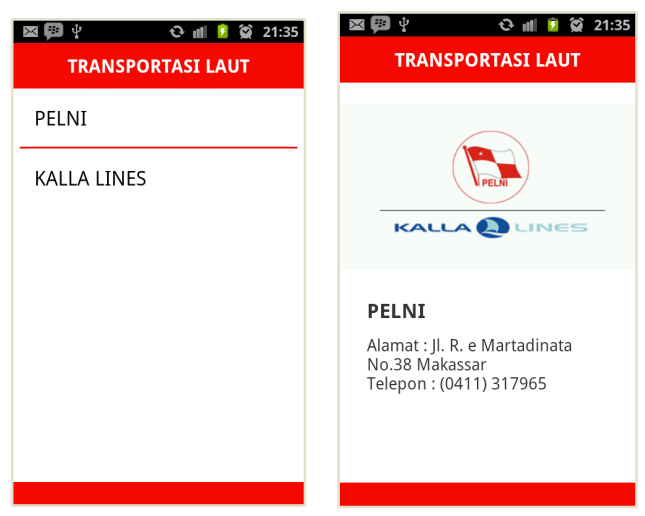

Gambar V.20 Antarmuka Informasi Transportasi Perusahaan Pelayaran

Tombol perusahaan pelayaran menampilkan informasi perusahaan kapal yang ada di Provinsi Sulawesi Selatan.

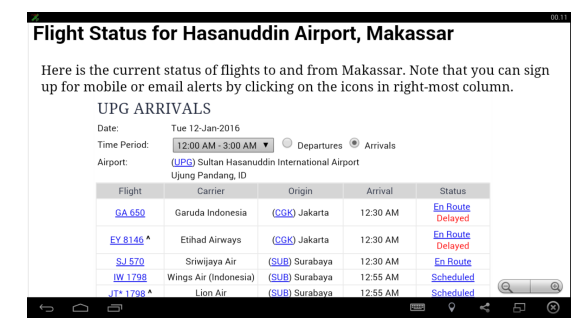

Gambar V.21 Antarmuka Informasi Transportasi Status Penerbangan

Tombol status penerbangan menghubungkan aplikasi dengan situs informasi flight status seluruh bandara di Asia namun disini dikhususkan untuk Bandar Udara Hasanuddin Makassar yakni, http://asiaairports.com/indonesia/upg/flight-status.php.
Diharapkan dengan ini pengguna dapat mudah melihat jadwal penerbangan untuk manajeman perjalanan pengguna.

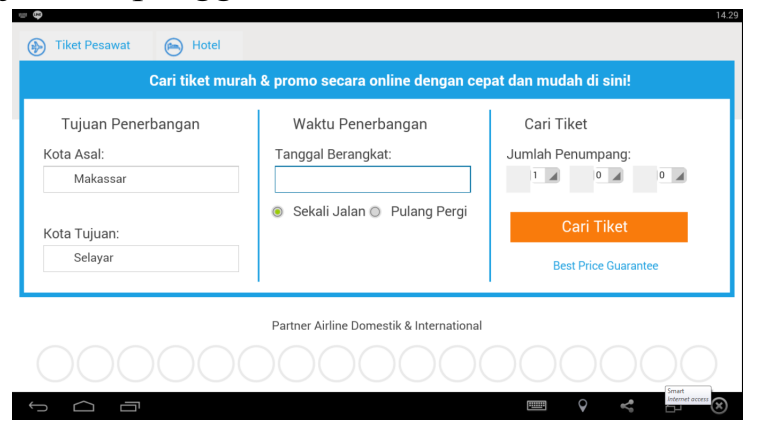

Gambar V.22 Antarmuka Reservasi Online Tiket Pesawat

Tombol reservasi online tiket pesawat menghubungkan aplikasi dengan situs reservasi online tiket pesawa yakni, http://traveloka.com.

r. Antarmuka Agen Perjalanan

Antarmuka agen perjalanan menyediakan informasi umum dari beberapa agen tour dan travel yang ada di Provinsi Sulawesi Selatan.

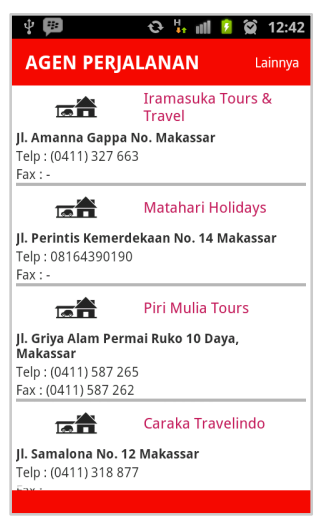

Gambar V.23 Antarmuka Agen Perjalanan

s. Antarmuka Tips dan Trik Wisata

Tips dan trik wisata pada antarmuka ini, bersumber dari Indonesia travel (Kementerian Pariwisata dan Ekonomi Kreatif Republik Indonesia)

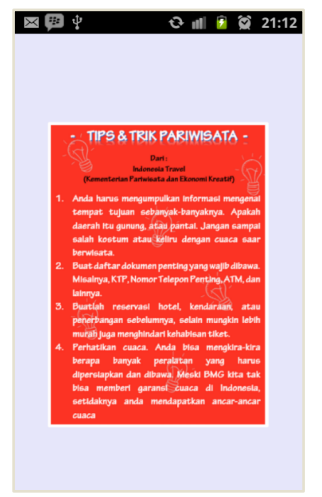


Gambar V.24 Antarmuka Tips dan Trik Wisata

t. Antarmuka Telepon Penting

Antarmuka ini menyediakan list nomornomor penting yang ada di Provinsi Sulawesi Selatan, dari list yang dipilih dapat langsung melakukan panggilan.
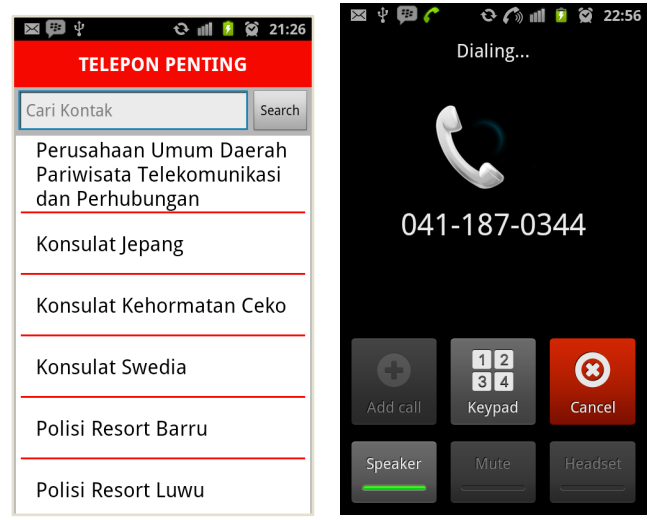

Gambar V.25 Antarmuka Telepon Penting

u. Antarmuka Profil Aplikasi

Antarmuka profil aplikasi menampilkan dua tabs yaitu profil dan kontak. Tabs profil memberi informasi tentang profil aplikasi, informasi aplikasi, dan referensi aplikasi. Sementara tabs kontak, menampilkan kontak pribadi pembuat aplikasi.

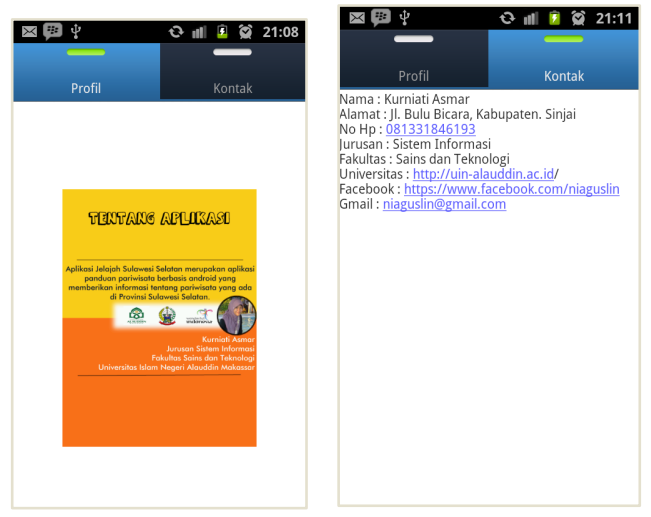

Gambar V.26 Antarmuka Profil Aplikasi

\section{KESIMPULAN}

Dari pembahasan yang telah dijabarkan pada bab-bab sebelumnya, ditarik kesimpulan bahwa Aplikasi Jelajah Sulawesi Selatan dapat dijadikan sebagai media panduan pariwisata Provinsi Sulawesi Selatan, sehingga Dinas Kebudayaan dan Pariwisata Provinsi Sulawesi
Selatan dapat lebih efisien dalam melakukan promosi pariwisata kepada masyarakat atau wisatawan agar tertarik berkunjung ke tempattempat wisata yang ada di Provinsi Sulawesi Selatan. Dari hasil pengujian Black Box aplikasi ini dapat menjalankan fungsi promosi pariwisata dengan baik dan efisien. Sementara dari hasil pengujian User Satisfaction, responden menyatakan setuju aplikasi ini lebih efisien digunakan untuk promosi pariwisata Provinsi Sulawesi Selatan.

\section{Daftar Pustaka}

Ananda, Ramdhana F. "Sistem Informasi Pariwisata" 7020121237 . http://7020121237.blogspot.com/2012/11/sisteminformasi-pariwisata.html\# (23 Oktober 2015)

"Aplikasi". Kamus Besar Bahasa Indonesia.http://kbbi.web.id/aplikasi (05 Juli 2015).

Muharrom, Arzan., dkk. "Pengembangan Aplikasi Sunda berbasis Android Menggunakan Metode Rapid Application Development". Jurnal Algoritma 10, no. 1(2013): h. 2-11.

Nasution, S. "Berbagai Pendekatan Dalam Proses Belajar Mengajar". Bandung: Bumi Aksara (2008)

Aslianti. "Sistem Informasi Georafis Wisata Budaya dan Sejarah Kota Makassar Berbasis Web". Skripsi Sarjana, Fakultas Sains dan Teknologi Universitas Islam Negeri Alauddin, Makassar, 2011.

Bukhori, Imam. "Rancang Bangun Sistem Informasi pariwisata Berbasis E-Tourism Kabupaten Pacitan". Skripsi Sarjana, Fakultas Sains dan Teknologi Universitas Islam Negeri Maulana Malik Ibrahim, Malang, 2010. 
Departemen Agama R.I., Lajnah Pentashih Mushaf Al-Qur'an. Syaamil Al-Qur'an. Edisi Revisi. Bandung: PT Syaamil Cipta Media, 2004.

Dinas Kebudayaan dan Pariwisata Provinsi Sulawesi Selatan. Pengenalan Kebudayaan dan Pariwisata Sulawesi Selatan. Makassar, 2010

HM, Jogiyanto. "Analisis dan Desain Sistem Informasi : Pendekatan Terstruktur Teori dan Praktek Bisnis". Yogyakarta: ANDI (1999).

HM, Jogiyanto. "Analisis dan Desain Sistem Informasi”. Yogyakarta: ANDI (2005). 